\title{
Commentary
}

\section{Client cum domain segmentation approach for sustaining essential commodities supply system in Indian states/UTs under lockdown due to COVID-19 pandemic}

\author{
Ishwarpreet Kaur*, Amarjeet Singh
}

\begin{abstract}
Department of Community Medicine and School of Public Health, Post Graduate Institute of Medical Education and Research, Chandigarh, India
\end{abstract}

Received: 15 June 2020

Accepted: 10 July 2020

*Correspondence:

Dr. Ishwarpreet Kaur,

E-mail: missive4@gmail.com

Copyright: (C) the author(s), publisher and licensee Medip Academy. This is an open-access article distributed under the terms of the Creative Commons Attribution Non-Commercial License, which permits unrestricted non-commercial use, distribution, and reproduction in any medium, provided the original work is properly cited.

\section{INTRODUCTION}

World Health Organization (WHO) declared corona virus disease 2019 (COVID-19) a pandemic on 11 March 2020. A disease caused by severe acute respiratory syndrome corona virus 2 (SARS-CoV-2). ${ }^{1}$ Worldwide more than 100 countries are affected by it, with $2,878,196$ confirmed cases (as per WHO situational report 27 April 2020). ${ }^{2}$ In India, the confirmed cases so far are 29,435 and 934 deceased (as on 28 April 2020). ${ }^{3}$ The spread of virus is postulated to be in stage 2 .

In an effort to curb the community spread (stage 3 ) of COVID-19, the Prime Minister of India announced on 24th March 2020, a 3-week lockdown for the entire nation. It was extended up to April 21 and then up to May 3. The goal of this lockdown was to maintain social distancing which can stop the transmission of virus to healthy population.

Prime Minister again interacted with the CMs through video conferencing on 27th April 2020. They discussed regarding graded exit plan from the lockdown/curfew. Few states (in red zones/hot spots) were in favour of extending the lockdown while a few asked for relaxation. The government has now come up with a plan that not just curtails the spread of COVID-19 but also revives the Indian economy. ${ }^{4}$

To mitigate the effect of corona crisis, curfews and lock downs were imposed all over the country. Restricting the movement of people along with suspension of train, truck and bus services had grossly affected the livelihood of millions and supply chain of many commodities. This added to the problems of people. There was panic in the public not just about the disease but also how to sustain life in these restrictive times. Migrants are heading out to leave for their native homes while many residents are leaving homes for collecting daily supplies even at time of curfew/lockdown.

Various states' and UTs' administrations in India developed their strategic plans to deal with the situation. The main focus of the plan were to strengthen health care system to combat patient load and emergencies related to the disease. The police and along with civic bodies were also working towards providing essential commodities to the citizens at doorsteps. They are trying to feed the poor and migrant section of the society and simultaneously ensuring compliance to lockdown.

In spite of many efforts by the administration, the implementation of its plans is not fool proof with doubtful efficiency. Few states/UTs have been more successful than the others. But overall, many lapses were reported in social and print media.

It is also imperative to understand that the onus of success of this lockdown depends on both the administration and the public. In this article, we tried to understand the intricacies of the current situation, identify gaps/lapses and give our suggestions. After 35 days of lockdown, we have tried to analyse the situation of our city beautiful 
'Chandigarh' and proposed practical solutions to tackle the same.

Thus, the present study was planned with the objective to analyze the status of essential commodities supply system in Chandigarh.

\section{METHODS}

The present study was conducted in Chandigarh. Data was collected through interviews (telephonic/online), observations and content analysis of media reports. Many people were interviewed regarding their experiences in lockdown and anecdotes were studied. Newspaper and TV news reports, websites content was analysed along with observations. Principle of redundancy was followed for sample size. Based on the analysis suggestions / recommendations were made.

\section{PROBLEMS/LAPSES}

The first two days the city witnessed strict curfew. Police naakkaas/check points were there at every major road of the city. Hardly few vehicles were on road; obviously, of the essential service providers who had to continue their duties at this point. However, by the end of the third day the situation became quite lenient. Non-conformists increased as the deployment of police decreased within the residential areas. Restless, bored and unable to channelize energies people just wanted to go out for change. In few sectors, people were seen walking on roads, purchasing from stores, kids playing in parks. Violating curfew rules and paying no heed to social distancing. Vehicular traffic also increased, people were going in cars and two wheelers to fetch daily need items.

However, in the present situation, we can find little laxity in planning and implementation. It is a new situation for everyone. Even the administration is trying its best to tackle the crisis in the best possible way without causing any inconvenience to the residents of city. Even they are trying hit-and-trial techniques to come out with best possible plans and policies.

In one such scenario, initially the administration had thought off providing door-to-door services to the residents. They came up with list of stores/vendors that were to do the job. But as it was realised that providing such services was not feasible, this initiative was later modified.

In the initial few weeks the supply of newspaper and waste collection was hampered. The shops were not providing home deliveries for orders below Rs. 600/-, majority of whom only accepted cash payments. People had cash crunch. The banks and ATMs were closed. The shopkeepers also asked to send WhatsApp messages for their orders. Many senior citizens and poor people who were not tech savvy, hence could not have such facilities.
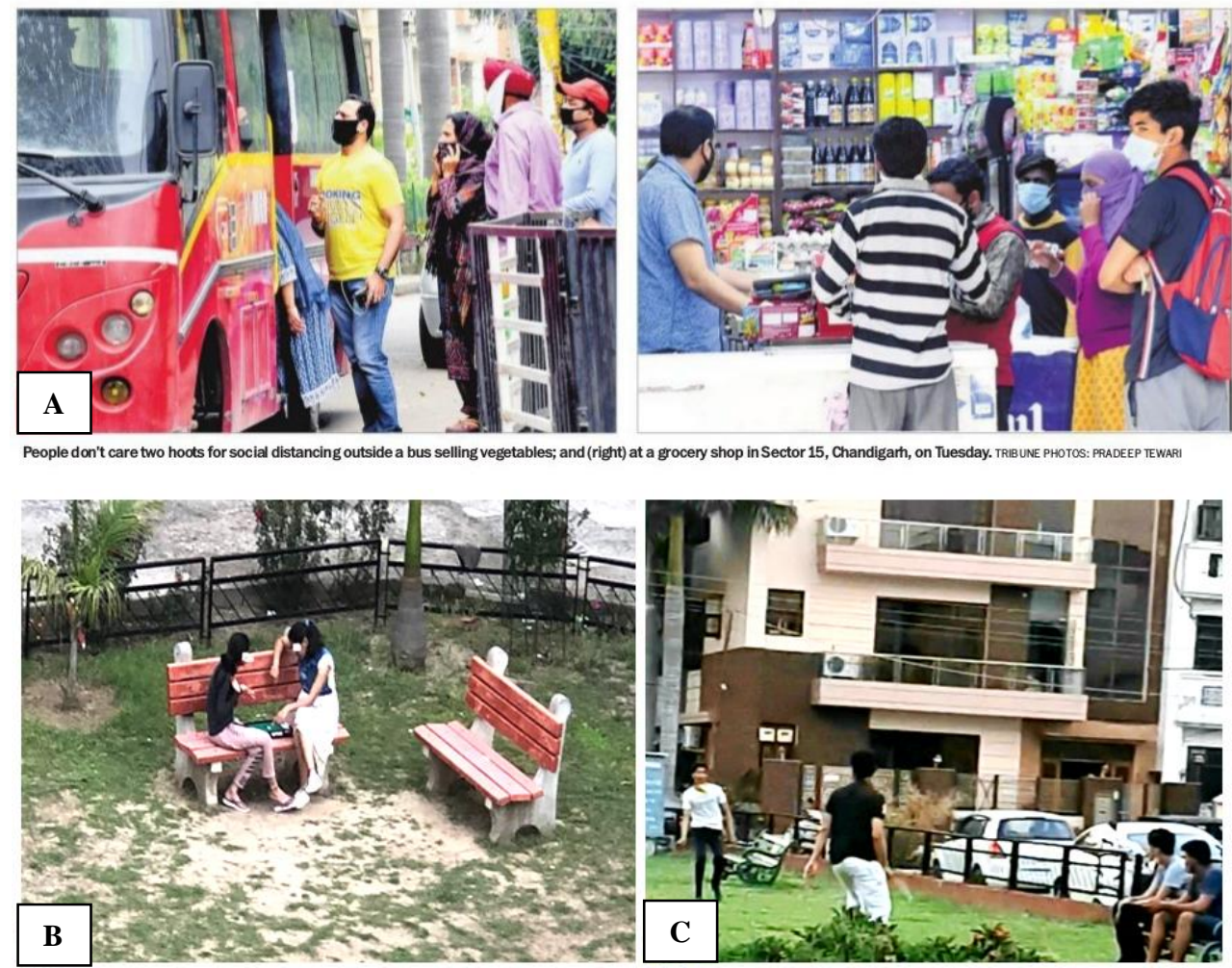

Figure 1: (A) Customers not maintaining 1-meter safe physical distance while purchasing essential commodities; (B and C) kids playing in park during lockdown.

Image source: A: The Tribune, B and C: Dr Nisha, MPH student, PGIMER. 
The vendors were not coming to residential localities and the ones who came were over charging for the fruits and vegetables. The listed vendors for each sector never turned up. Every time it was a different vendor. Later, city bus service was introduced for supplies. Many of the residents were not aware of this initiative. They still waited for their door-to-door vending carts. The huge buses never reached the interiors of sectors with narrow roads. Where it reached, people did not maintain proper distance while purchasing the vegetables etc. The timings and place were not fixed. The vendors were asked to purchase the commodities on their own. As they had limited cash, they could only procure very less vegetables/fruits which would exhaust soon. This left many residents without vegetables/fruits. Many were seen purchasing large quantities of food items. No limit was imposed on the amount being purchased by a single person. The vendors were not wearing masks. The ones wearing only covered their mouth and not the nose. People crowded the carts and did not pay any heed to social distancing.

The lapses are clearly highlighted in the Figure 1 (A-C).

Another major issue was the accuracy of information provided on Chandigarh's official portal. The vendors mentioned in list were not providing services at the designated areas as per the list. They were not answering calls.

Other problems surfaced after the fourth day when administration lifted curfew and allowed people to get goods from shops between 10 am to 6:00 pm. Neither the shopkeeper nor the customer followed social distancing. More than 8-10 people were seen entering shops in one go. Hand sanitization was not followed while entering shops. Even if the police demarcated lines to maintain enough distance, it was hardly followed. Nowhere, the demarked lines were one meter apart.

However, many of these problems were resolved in the later weeks. But, still, few persist like the social distancing not appropriately and adequately followed. The vegetable/fruit bus service has no fixed timings and place. It's hard to locate the bus in sectors especially by foot in hot summer days. Timing of shop opening changed repeatedly (earlier it was from 11:00 am to 3:00 pm now its 10:00 am to 2:00 pm. The stocks of branded items also exhausted. People could not get preferred brands of essential items. Options are limited even now. The routine practices/choices are changing due to compulsion.

\section{Some stories/experiences shared by MPH students and staff of PGIMER from their residential areas in Chandigarh during the curfew and lockdown period}

Verbatim 1: "Sector 34, sweepers are cleaning, garbage is being collected, people following lockdown even kids, but have to go out to get supplies, vegetable vendor comes but they are expensive."

Verbatim 2: "People still do not understand the gravity of the situation, can see people going around for morning and evening walks, supply of essential commodities is affected, no home delivery of ration and vegetables as promised. To buy grocery and stuff, one has to move out and then they are harassed by the police. Also reports of hoarding and black marketing. Today vegetable vendor came after 5 days. People not adhering to curfew but government has to ensure supply of essential commodities."

Verbatim 3: "Sector 51D, supply of all essentials to the society is there (non essentials chips, chocolates not there as supply is stopped from back end), people try to go to park but police keep an eye and send them back. Garbage collection is regular...."

Verbatim 4: "In PGI, supply of essentials like milk and medicines is on from ODH and Gole market. Today onwards, a vegetable cart will be coming daily. As compared to regular days, the patient load has drastically reduced and there are hardly any vehicles on the otherwise busy roads.... Suggestions would be that regulations still need to be done in the way vegetable and grocery is being distributed."

Verbatim 5: "In sector 21, neither vegetable vendors are coming or the garbage collector. No vegetables were cooked for a whole week at my home. People are seen taking leisure walk during early morning and late evenings. Kids play in parks. The CTU bus service is erratic, has no fixed vending place or timings. The vegetables and fruits are sold at exuberant prices. No social distancing is maintained at chemist and grocery store."

\section{Solutions}

To overcome these challenges a client-cum-domain segmentation approach is required. In addition, a line listing of the essential commodities providers must be prepared and given appropriate training and personal protection equipments (PPEs) (masks, gloves, etc) in order to increase their adherence to hygiene \& safety measures (Figure 2). If the providers violate social distancing or do not wear proper PPE at work, they must be punished. As part of their training the essential service providers like police officers, vendors, shopkeepers, etc. must be taught importance and use of PPE; how they should themselves maintain social distancing at work/streets/shops and how they must ensure that the customers also maintain the same. They should be made aware that in case of any signs and symptoms of COVID19 they must immediately report to administration and stop working. Health officers should monitor the health of the providers periodically. The shops should only allow one customer at a time. To check any violation, random 
checking of CCTV footage of the shops needs to be done. The street vendors could be given body cameras or a police personal can be deputed along to check any violation of safe distancing. Posters showing 1 meter distance should be pasted outside shops. Vendors should also be given display cards related to maintaining social distancing.

Training regarding social distancing \& face mask usage/disposal

Health Screening

Monitoring and Surveillance

Identifying defaulters

Strict action / punishment for violators

Figure 2: Quality adherence by essential commodities providers.

Lockdown is not the same for everyone, which is evident from social media posts and print media. Celebrities posting workout videos / worried about showcasing their new jewellery/culinary skills, families posting selfies, the poor worried for their next meal and labour class swamping bus stands desperate to reach their hometowns.
Thus, the strategies need to be planned keeping in mind the service domains and the clientele. There is a need to formulate different administrative heads and teams for providing services to various clients.

Firstly, it is important to know who is staying where and comes under which category. It was witnessed that the shopkeepers could not keep up with doorstep delivery for every client. To solve such issues, we need to prioritize clients whom to provide services first.

There must be help line numbers working $24 \times 7$, and complaint service (telephonic call, message/internet/ police-beat box). Total lock down should be only for vulnerable population like elderly/disabled/quarantine and isolated.

The client-cum-domain segmentation matrix is developed for maintaining smooth supply of essential commodities to the citizens. As per this approach the following client categorization was identified - elderly or disabled (living alone), poor/daily wagers/below poverty line, quarantine/ isolated, homeless and other healthy population. The essential commodities were segregated under the domain heads like medicine/pharma, vegetables/fruits, groceries, LPG/other form of fuels used for cooking, community kitchens organized under supervision of administrations, health emergencies, routine/general health care, waste collection, banks/ATM. The matrix highlights how these commodities should be supplied keeping in mind the clientele needs and requirements. There are other key points which could not be incorporated in the matrix are therefore mentioned below the matrix (Table 1).

Table 1: Client-cum-domain segmentation matrix for maintaining essential commodities supply system.

\begin{tabular}{|c|c|c|c|c|c|}
\hline Domain Client & $\begin{array}{l}\text { Elderly or } \\
\text { disabled } \\
\text { (living alone) }\end{array}$ & $\begin{array}{l}\text { Poor/daily } \\
\text { wagers/BPL }\end{array}$ & $\begin{array}{l}\text { Quarantine / } \\
\text { isolated }\end{array}$ & Homeless & $\begin{array}{l}\text { Other healthy } \\
\text { population }\end{array}$ \\
\hline $\begin{array}{l}\text { Medicines/ } \\
\text { Pharma }\end{array}$ & $\begin{array}{l}\text { Home delivery } \\
\text { (on call basis) }\end{array}$ & $\begin{array}{l}\text { Free procurement } \\
\text { from PHCs, CHCs, } \\
\text { District hospital, } \\
\text { dispensaries }\end{array}$ & $\begin{array}{l}\text { Free home delivery } \\
\text { by administration } \\
\text { (1/week or on call } \\
\text { basis) }\end{array}$ & $\begin{array}{l}\text { All facilities } \\
\text { to be } \\
\text { provided at } \\
\text { shelter } \\
\text { homes }\end{array}$ & $\begin{array}{l}\text { Collection from } \\
\text { chemist / } \\
\text { optional home } \\
\text { delivery }\end{array}$ \\
\hline $\begin{array}{l}\text { Vegetables/ } \\
\text { fruits }\end{array}$ & $\begin{array}{l}\text { Home delivery } \\
\text { (on call) }\end{array}$ & $\begin{array}{l}\text { Free vegs/fruits to } \\
\text { be delivered at } \\
\text { doorstep }\end{array}$ & $\begin{array}{l}\text { Free home delivery } \\
\text { by administration } \\
\text { ( } 2 / \text { week or on call } \\
\text { basis) }\end{array}$ & $\begin{array}{l}\text { All facilities } \\
\text { to be } \\
\text { provided at } \\
\text { shelter } \\
\text { homes }\end{array}$ & $\begin{array}{l}\text { Purchase from } \\
\text { vendors during } \\
\text { permitted hours } \\
\text { / optional home } \\
\text { delivery }\end{array}$ \\
\hline Groceries & $\begin{array}{l}\text { Home delivery } \\
\text { (on call) }\end{array}$ & $\begin{array}{l}\text { Free ration to be } \\
\text { delivered at } \\
\text { doorstep. }\end{array}$ & $\begin{array}{l}\text { Free home delivery } \\
\text { by administration } \\
\text { (1/week or on call } \\
\text { basis) }\end{array}$ & $\begin{array}{l}\text { All facilities } \\
\text { to be } \\
\text { provided at } \\
\text { shelter } \\
\text { homes }\end{array}$ & $\begin{array}{l}\text { Purchase from } \\
\text { shops during } \\
\text { permitted hours } \\
\text { / optional home } \\
\text { delivery }\end{array}$ \\
\hline $\begin{array}{l}\text { LPG/ other form } \\
\text { of fuels used for } \\
\text { cooking }\end{array}$ & $\begin{array}{l}\text { Home delivery } \\
\text { (on call) }\end{array}$ & $\begin{array}{l}\text { Free home delivery } \\
\text { LPG/ wood/ } \\
\text { kerosene oil/ } \\
\text { charcoal/cow dung } \\
\text { cakes }\end{array}$ & $\begin{array}{l}\text { Free home delivery } \\
\text { by administration } \\
\text { (when required) }\end{array}$ & $\begin{array}{l}\text { All facilities } \\
\text { to be } \\
\text { provided at } \\
\text { shelter } \\
\text { homes }\end{array}$ & $\begin{array}{l}\text { Home deliver } \\
\text { (on call) }\end{array}$ \\
\hline
\end{tabular}




\begin{tabular}{|c|c|c|c|c|c|}
\hline Domain Client & $\begin{array}{l}\text { Elderly or } \\
\text { disabled } \\
\text { (living alone) }\end{array}$ & $\begin{array}{l}\text { Poor/daily } \\
\text { wagers/BPL }\end{array}$ & $\begin{array}{l}\text { Quarantine / } \\
\text { isolated }\end{array}$ & Homeless & $\begin{array}{l}\text { Other healthy } \\
\text { population }\end{array}$ \\
\hline $\begin{array}{l}\text { Community } \\
\text { kitchens organized } \\
\text { under supervision } \\
\text { of administrations }\end{array}$ & $\begin{array}{l}\text { Pre-cooked food } \\
\text { tiffin service at } \\
\text { home (if unable } \\
\text { to cook) }\end{array}$ & $\begin{array}{l}\text { Can be shifted to } \\
\text { shelter homes / } \\
\text { provided cooked } \\
\text { foods }\end{array}$ & $\begin{array}{l}\text { Free pre-cooked } \\
\text { food tiffin service at } \\
\text { home } \\
\text { (If unable to cook) }\end{array}$ & $\begin{array}{l}\text { All facilities } \\
\text { to be } \\
\text { provided at } \\
\text { shelter } \\
\text { homes }\end{array}$ & - \\
\hline $\begin{array}{l}\text { Health } \\
\text { emergencies }\end{array}$ & $\begin{array}{l}\text { Mobile heath } \\
\text { vans for home } \\
\text { visit / ambulance } \\
\text { service }\end{array}$ & $\begin{array}{l}\text { Call nearest health } \\
\text { centre discuss } \\
\text { issues, if required } \\
\text { visit health centre } \\
\text { on appointment } \\
\text { basis to avoid } \\
\text { overcrowding / } \\
\text { ambulance service }\end{array}$ & $\begin{array}{l}\text { Mobile heath vans } \\
\text { for home visit / } \\
\text { ambulance service }\end{array}$ & $\begin{array}{l}\text { Doctor can } \\
\text { be posted at } \\
\text { shelter } \\
\text { homes for } \\
\text { minor issues } \\
\text { / ambulance } \\
\text { service }\end{array}$ & $\begin{array}{l}\text { Call nearest } \\
\text { health centre } \\
\text { discuss issues, } \\
\text { if required visit } \\
\text { health centre on } \\
\text { appointment } \\
\text { basis to avoid } \\
\text { overcrowding / } \\
\text { ambulance } \\
\text { service }\end{array}$ \\
\hline $\begin{array}{l}\text { Routine/general } \\
\text { health care }\end{array}$ & $\begin{array}{l}\text { Telemedicine } \\
\text { consultations - } \\
\text { Doctors on call } \\
\text { (who are not tech } \\
\text { savvy) } \\
\text { Others can use } \\
\text { website link } \\
\text { (PGIMER } \\
\text { website), skype, } \\
\text { watch \& } \\
\text { download } \\
\text { YouTube videos } \\
\text { on health care }\end{array}$ & $\begin{array}{l}\text { Telemedicine } \\
\text { consultations - } \\
\text { Doctors on call } \\
\text { (who are not tech } \\
\text { savvy) } \\
\text { Others can use } \\
\text { website link } \\
\text { (PGIMER website), } \\
\text { skype, watch \& } \\
\text { download YouTube } \\
\text { videos } \\
\text { on health care }\end{array}$ & $\begin{array}{l}\text { Telemedicine } \\
\text { consultations - } \\
\text { Doctors on call } \\
\text { (who are not tech } \\
\text { savvy) } \\
\text { Others can use } \\
\text { website link } \\
\text { (PGIMER website), } \\
\text { skype, watch \& } \\
\text { download YouTube } \\
\text { videos } \\
\text { on health care }\end{array}$ & $\begin{array}{l}\text { Doctor can } \\
\text { be posted at } \\
\text { shelter } \\
\text { homes for } \\
\text { minor issues }\end{array}$ & $\begin{array}{l}\text { Telemedicine } \\
\text { consultations - } \\
\text { Doctors on call } \\
\text { (who are not } \\
\text { tech savvy) } \\
\text { Others can use } \\
\text { website link } \\
\text { (PGIMER } \\
\text { website), skype, } \\
\text { watch \& } \\
\text { download } \\
\text { YouTube } \\
\text { videos } \\
\text { on health care }\end{array}$ \\
\hline Waste collection & Home collection & Home collection & $\begin{array}{l}\text { Separate } \\
\text { Collection (bio } \\
\text { hazardous waste) }\end{array}$ & $\begin{array}{l}\text { Shelter } \\
\text { home } \\
\text { collection }\end{array}$ & $\begin{array}{l}\text { Home } \\
\text { collection }\end{array}$ \\
\hline Banks/ATM & $\begin{array}{l}\text { Mobile } \\
\text { ATM vans at } \\
\text { doorstep/ } \\
\text { Withdraw cash } \\
\text { by cheque service } \\
\text { at doorstep }\end{array}$ & $\begin{array}{l}\text { Govt can provide } \\
\text { relief in form of } \\
\text { cash transfer } \\
\text { through bank } \\
\text { accounts }\end{array}$ & - & - & $\begin{array}{l}\text { From banks / } \\
\text { ATM during } \\
\text { permitted hours }\end{array}$ \\
\hline
\end{tabular}

\#\#Under the patronage of Dr Jagat Ram (Director, PGIMER), Department of Community Medicine and School of Public Health, PGIMER, Chandigarh has created their own YouTube Channel that showcases short videos on corona awareness and other minor health issues of women, who may not be able to access routine obstetrics and gynaecology care due to curfew during corona crisis. Screen shot of one such video is given below. Also, the people can have access to health education material on various routine health care issues from the PGIMER website (Figure 3). ${ }^{6}$ The steps to access this educational content are: Step 1: Open any search engine. For e.g. Google. Step 2: Type http://pgimer.edu.in/ in the search box. The PGIMER website link will open. Step 3: Click on Public forum, one of the main links mentioned below the PGIMER name. A drop down menu will appear. Step 4: Next click on patient empowerment. This will take you to all the IEC available for various health conditions. Click which on them to download or read.

*Other key points to be considered: Every person must have the option to shift to shelter home, if they are unable to arrange essential commodities for themselves. The shelter homes should not ask for any proof of identification. The administration must take responsibility for providing all basic essential services to them free of cost / at nominal fee if the person can afford. Every facility should be planned keeping in mind that majority people are not technology savvy. Online or WhatsApp ordering for home deliveries is not possible for non-tech savvy people. The mobile companies must allow daily free calling for minimum of 15-30 minutes on all mobile numbers. The rate list of all essential commodities should be daily updated and printed in newspaper or available online. It must be made compulsory for vendors and shopkeepers to display the rate list. Electricity services, plumbing and AC services should also be included in utility services. Few shops for working population should be allowed to extend their timings beyond 5 pm so that they can purchase especial commodities. The administration can arrange for an online/ telephone-based centralized delivering system through which they can cover the majority of the houses. Everything can be pre-packed in disinfected pouches/parcels. This matrix and the recommendations will act as a blue print for the administration to take prompt and effective action for the benefit of clients. Thus, avoiding unnecessary confusion, discomfort and harassment to the citizens from all walks of life. 


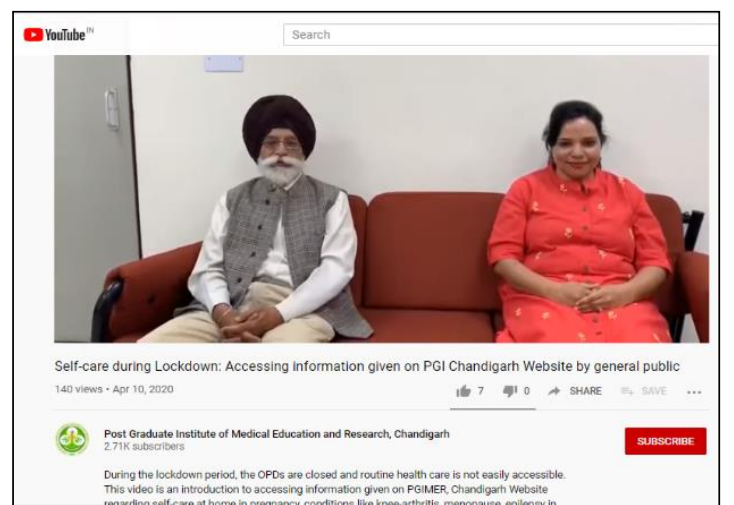

(A)

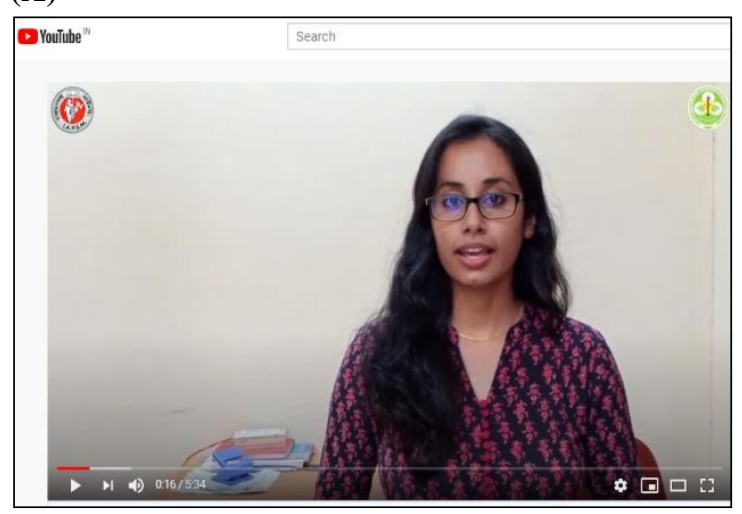

(C)
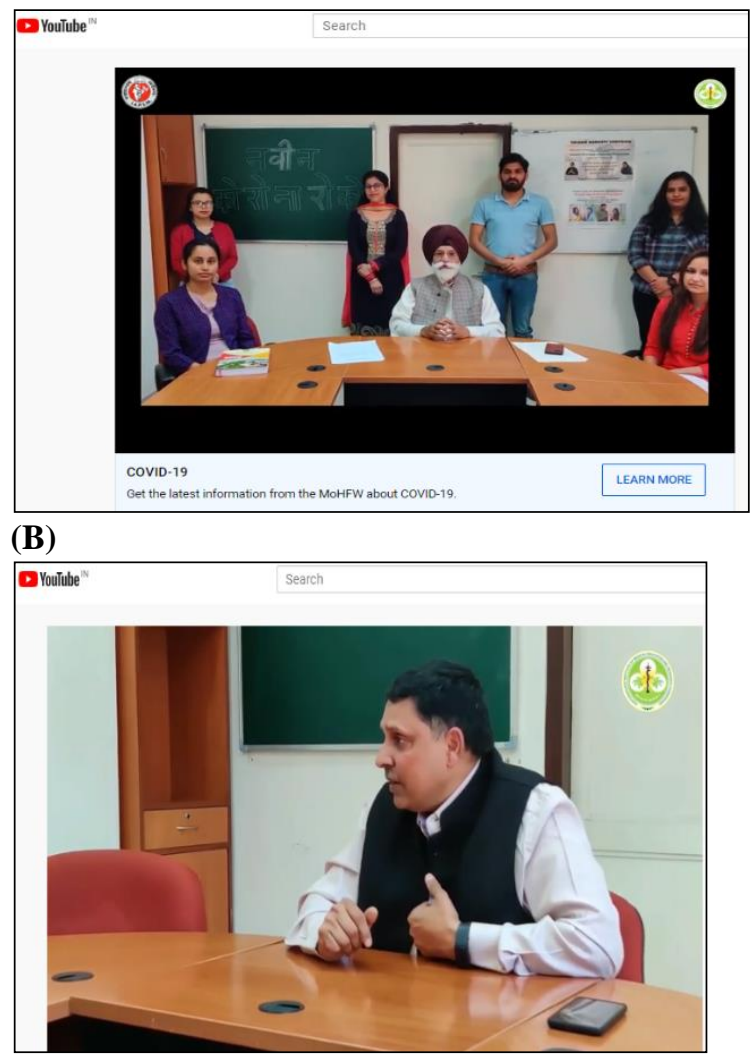

(D)

Figure 2 (A-D): Screen shots of health awareness videos.

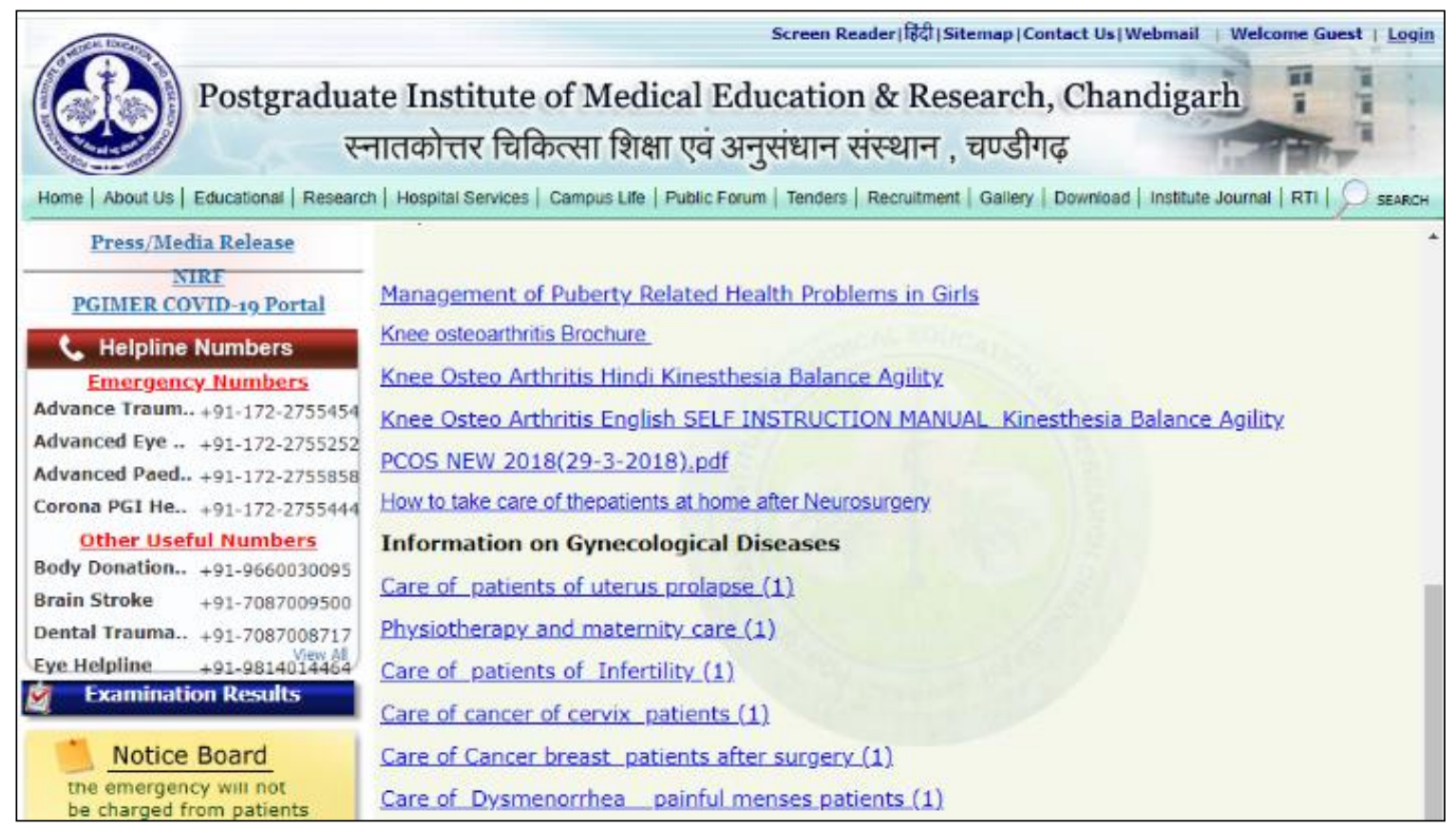

Figure 3: Screen shot of health education material available on PGIMER website.

\section{CONCLUSION}

In the past, the world has experienced many health crisis like SARS, MERS, H1N1, etc. but nothing as overwhelming as COVID-19. This experience of failure and success has taught us a lot about managing food, health and other civil services at time of such crisis. Many SOPs, strategies and plan of actions have been formulated. These solutions can be used as standard operating procedures or ready to go to guidelines for 
tackling future public health crisis. Also, the societies have to accept the fact that the onus of success of tackling such problems depends equally on the administration and the public.

\section{REFERENCES}

1. World Health Organization. Naming the coronavirus disease (COVID-19) and the virus that causes it. Available at: https://www.who.int/emergencies/ diseases/novel-coronavirus-2019/technical-guidance/naming-the-coronavirus-disease-(covid-2019)and-the-virus-that-causes-it. Accessed on 28 April 2020.

2. World Health Organization. Coronavirus disease 2019 (COVID-19) Situation Report - 98. Available at: https://www.who.int/docs/default-source/corona viruse/situation-reports/20200427-sitrep-98-covid19.pdf?sfvrsn=90323472_4. Accessed on 28 April 2020.

3. Ministry of Health \& Family Welfare. COVID-19 India as on: 27 April 2020, 08:00. Available at: https://www.mohfw.gov.in/. Accessed on 28 April 2020.
4. Tribune News Service and PTI. Focus on economy, hotspots: PM. The Tribune. 28 April 2020. P 1. Available at: https://epaper.tribuneindia.com/ 2650655/The-Tribune/TT-28-April-2020\#clip/51369044/09f01b32-8efe-4611-b3f9-8ff378e67d51/ 1031.111111111111:893.338370879973. Accessed on 29 April 2020.

5. Tiwari, Pradeep. Norms go for a toss. The Tribune, Chandigarh. 1 April 2020. P 2. Available at: https://epaper.tribuneindia.com/2616575/Chandigar h-Tribune/CT-01-April-2020\#page/2/1. Accessed on 2 April 2020.

6. Post Graduate Institute of Medical Education and Research. Available at: http://pgimer.edu.in/PGIMER_PORTAL/PGIMERPORTAL/home.jsp. Accessed on 28 April 2020.

Cite this article as: Kaur I, Singh A. Client cum domain segmentation approach for sustaining essential commodities supply system in Indian states/UTs under lockdown due to COVID-19 pandemic. Int J Community Med Public Health 2020;7:3312-8. 